\title{
Development and Sensory Evaluation of Meat Analog
}

\author{
B.R. Nivetha*, K. Sudha, Rita Narayanan and M. Vimalarani \\ Food Technology, Tamil Nadu Veterinary and Animal Sciences University, College of Food \\ and Dairy Technology, Koduveli, Chennai, India \\ *Corresponding author
}

Keywords

Meat analog,

Mushroom, Paneer,

Sensory evaluation

Article Info

Accepted:

12 July 2019

Available Online:

10 August 2019

\section{A B S T R A C T}

The present study was conducted to develop a meat analog which satisfies the need of meat for both vegetarians and non-vegetarians. Meat analog is a product produced from vegetarian ingredients but it resembles the meat in both nutritional and sensory characteristics. Meat analog was prepared from mushroom as a base, blended with different proportions of paneer and wheat gluten flour. Gluten flour was used as texturizing agent and spices such as ginger, garlic, coriander powder, pepper, chilli powder and salt were used for flavouring the product. Totally 10 treatments were tried with different proportions of ingredients, which also includes one control which is a meat nuggets. A standard product was developed which replaces the meat in a recipe, both in nutritional and sensory characteristics. Sensory evaluation of the product was done using 9 point hedonic scale. 50:30:20 ratio of mushroom, paneer and wheat gluten flour score highest overall acceptability compared with control.

\section{Introduction}

Vegetarian foods occupy a larger part than ever shelf space in today's market due to the increasing rate of consumer health concerns and the related environmental issues (Craig 2010). Researches on vegetarianism focused mainly on potential nutritional deficiencies in the previous studies. But in recent studies, researches confirm the potential health benefits of meat-free eating. In recent times, plant-based eating is recognized as not only nutritionally sufficient but also as a way to reduce the risk in all other health aspects. Compared to meat eaters, vegetarians tend to consume less saturated fat and cholesterol, and more vitamins $\mathrm{C}$ and $\mathrm{E}$, dietary fiber, folic acid, potassium, magnesium, and phytochemicals such as carotenoids and flavonoids. Though there are lots of vegetarian foods the variety for meat analog is very minimum. In the current scenario people prefer a variety in vegetarian foods. The market for meat analog does not only include vegetarians but also non-vegetarians who seek to reduce the meat consumption for health concerns and ethical 
reasons. Developing new products that are attractive to the consumers is a challenge. However it is slightly difficult to make these new foods, a substitute for products that are highly appreciated and accepted like meat (Joshi et al., 2015). Meat analog is a food products which are made from non-animal protein and its appearance and smell are very much similar to meat (Kumar et al., 2017).

Mushrooms are considered to be a good source of proteins, while lipid content is low. Fresh mushrooms are also a good source of minerals (Michele Sadler, 2003). Mushroom possess umami flavor which is due to the sulphur containing amino acids and it imparts meaty taste for the product. Milk and milk products are proved to be an excellent source of vital nutrients and functional components. It is described as nature's nearly perfect food and some leading experts recognize milk and its product as important constituents of a wellbalanced and nutritionally adequate diet. Paneer has good amount of fat and protein, low level of sugar, minerals and vitamins (Chitranayak et al., 2017). At present gluten is not only used in baking industry for cake, bread etc., but also used in all food industry making themselves a significant ingredient. Gluten has been utilized as a basic material in various protein foods of vegetable derivation to achieve a texture which simulates that of meat and meat products (Day et al., 2006). Moreover the craze towards non-vegetarian food stuffs aggregates as compared to vegan diet. At this intimidating scenario, the idea of development of meat analog is the need of the hour to feed the ever growing population looking for meat products.

\section{Materials and Methods}

\section{Development of meat analog emulsion}

The development of meat analog involved grinding of freshly blanched button mushrooms which is then blended with paneer and gluten flour in different proportions to form a protein emulsion. Various trails with different proportion of ingredients were conducted and the experimental trials were compared with control. Based on the sensory analysis using 9-point hedonic scale, 50:30:20 ratio of mushroom, paneer and wheat gluten flour respectively, obtained highest scores by the panelist (Table 1). Flow chart of steps for standardization of meat analog emulsion and preparation of meat analog product are presented in Figure 1 and 2.

\section{Sensory analysis of meat analog product}

The meat analog samples were evaluated for its acceptability, during the process of optimization. For sensory evaluation meat analog samples were subjected to a panel of thirty panelists consisting of faculties and PG students from the College of Food and Dairy Technology. The panelists were asked to evaluate the sensory quality of meat analog samples as per sensory score card.

Panel members were directed to judge each samples on the basis of appearance, flavor, taste, juiciness, texture and overall acceptability, and indicate their degree of liking on a 9-point Hedonic Scale.

\section{Results and Discussion}

\section{Optimizing the proportion of ingredients in the preparation of meat analog by sensory evaluation}

Sensory evaluation was done based on 9 point hedonic scale as given by Archana et al., (2016). The mean \pm SE scores of appearance, flavour, taste, juiciness, texture and overall acceptability of meat analogue optimized by adding different proportion of ingredients and their statistical analysis were presented in Table 2. 
Table.1 Optimization of different levels of Mushroom, Paneer, Corn flour and Wheat gluten flour in the preparation of meat analog emulsion

\begin{tabular}{|c|c|c|c|c|c|}
\hline Treatments & $\begin{array}{c}\text { Fresh Meat } \\
(\mathbf{\%})\end{array}$ & Mushroom (\%) & Paneer $(\mathbf{\%})$ & $\begin{array}{c}\text { Corn flour } \\
(\boldsymbol{\%})\end{array}$ & $\begin{array}{c}\text { Wheat gluten } \\
\text { flour }(\mathbf{\%})\end{array}$ \\
\hline Control & 100 & - & - & - & - \\
\hline T1 & - & 50 & 50 & - & - \\
\hline T2 & - & 50 & 45 & 5 & - \\
\hline T3 & - & 50 & 40 & 10 & - \\
\hline T4 & - & 50 & 35 & 15 & - \\
\hline T5 & - & 50 & 30 & 20 & - \\
\hline T6 & - & 50 & 30 & 15 & 5 \\
\hline T7 & - & 50 & 30 & 10 & 10 \\
\hline T8 & - & 50 & 30 & 5 & 15 \\
\hline T9 & - & 50 & 30 & - & 20 \\
\hline T10 & - & 50 & 30 & - & 25 \\
\hline
\end{tabular}

Table.2 Optimizing the proportion of ingredients in the preparation of meat analog by sensory evaluation (Mean \pm SE)

\begin{tabular}{|c|c|c|c|c|c|c|}
\hline \multirow[t]{2}{*}{ Treatments } & \multicolumn{6}{|c|}{ Sensory attributes (9-point hedonic scale) } \\
\hline & Appearance & Flavour & Taste & Juiciness & Texture & $\begin{array}{c}\text { Overall } \\
\text { acceptability }\end{array}$ \\
\hline Control & $8.60^{\mathrm{e}} \pm 0.170$ & $8.58^{\mathrm{e}} \pm 0.174$ & $8.66^{\mathrm{e}} \pm 0.177$ & $8.20^{\mathrm{h}} \pm 0.141$ & $8.60^{\mathrm{f}} \pm 0.170$ & $8.54^{f} \pm 0.166$ \\
\hline T1 & $5.44^{\mathrm{a}} \pm 0.172$ & $5.40^{\mathrm{a}} \pm 0.178$ & $6.24^{\mathrm{a}} \pm 0.081$ & $6.18^{\mathrm{a}} \pm 0.086$ & $5.24^{\mathrm{a}} \pm 0.092$ & $5.44^{\mathrm{a}} \pm 0.172$ \\
\hline T2 & $5.56^{\mathrm{a}} \pm 0.163$ & $5.62^{\mathrm{a}} \pm 0.177$ & $6.32^{\mathrm{ab}} \pm 0.086$ & $6.26^{\mathrm{ab}} \pm 0.092$ & $5.28^{\mathrm{ab}} \pm 0.086$ & $5.54^{\mathrm{ab}} \pm 0.172$ \\
\hline T3 & $5.82^{\mathrm{ab}} \pm 0.188$ & $5.86^{\mathrm{ab}} \pm 0.188$ & $6.64^{\mathrm{abc}} \pm 0.081$ & $6.48^{\mathrm{abc}} \pm 0.115$ & $5.56^{\mathrm{ab}} \pm 0.092$ & $5.60^{\mathrm{ab}} \pm 0.216$ \\
\hline T4 & $5.96^{\mathrm{ab}} \pm 0.180$ & $5.94^{\mathrm{ab}} \pm 0.177$ & $6.76^{\mathrm{bc}} \pm 0.074$ & $6.66^{\mathrm{abcd}} \pm 0.092$ & $5.72^{\mathrm{b}} \pm 0.086$ & $5.98^{\mathrm{abc}} \pm 0.174$ \\
\hline T5 & $6.24^{\mathrm{bc}} \pm 0.180$ & $6.20^{\mathrm{ab}} \pm 0.170$ & $7.14^{\mathrm{cd}} \pm 0.092$ & $6.74^{\mathrm{bcd}} \pm 0.092$ & $6.70^{c} \pm 0.094$ & $6.30^{\mathrm{bc}} \pm 0.194$ \\
\hline T6 & $6.72^{\mathrm{c}} \pm 0.185$ & $6.62^{\mathrm{bc}} \pm 0.180$ & $7.36^{\mathrm{d}} \pm 0.092$ & $6.88^{\mathrm{cde}} \pm 0.086$ & $6.88^{\mathrm{c}} \pm 0.080$ & $6.58^{\mathrm{cd}} \pm 0.174$ \\
\hline T7 & $7.22^{\mathrm{d}} \pm 0.188$ & $7.24^{\mathrm{cd}} \pm 0.163$ & $7.64^{\mathrm{d}} \pm 0.074$ & $7.06^{\mathrm{def}} \pm 0.092$ & $7.36^{\mathrm{d}} \pm 0.092$ & $7.18^{\mathrm{de}} \pm 0.168$ \\
\hline T8 & $8.08^{\mathrm{e}} \pm 0.185$ & $8.02^{\mathrm{de}} \pm 0.180$ & $8.30^{\mathrm{e}} \pm 0.100$ & $7.38^{\mathrm{efg}} \pm 0.066$ & $8.10^{\mathrm{e}} \pm 0.089$ & $7.98^{\mathrm{ef}} \pm 0.188$ \\
\hline T9 & $8.46^{\mathrm{e}} \pm 0.166$ & $8.42^{\mathrm{e}} \pm 0.165$ & $8.44^{\mathrm{e}} \pm 0.163$ & $7.86^{\mathrm{h}} \pm 0.128$ & $8.30^{\mathrm{f}} \pm 0.083$ & $8.46^{\mathrm{f}} \pm 0.166$ \\
\hline T10 & $8.26^{\mathrm{e}} \pm 0.081$ & $8.28^{\mathrm{e}} \pm 0.102$ & $8.30^{\mathrm{e}} \pm 0.100$ & $7.42^{\mathrm{fg}} \pm 0.128$ & $8.00^{\mathrm{e}} \pm 0.089$ & $8.28^{\mathrm{f}} \pm 0.128$ \\
\hline F value & $51.21 * *$ & $51.05 * *$ & $68.32 * *$ & $38.41 * *$ & $166.19 * *$ & $49.28 * *$ \\
\hline
\end{tabular}

@ Average of six trials

Means bearing various superscripts in the same column differs highly significantly $(P \leq 0.01)$

** Statistically highly significant $(P \leq 0.01)$

Control - Raw minced chicken meat (100\%)

T1 - Mushroom (50): Paneer (50)

T2 - Mushroom (50): Paneer (45): Corn flour (5)

T3 - Mushroom (50): Paneer (40): Corn flour (10)

T4 - Mushroom (50): Paneer (35): Corn flour (15)

T5 - Mushroom (50): Paneer (30): Corn flour (20)

T6 - Mushroom (50): Paneer (45): Corn flour (15): Wheat gluten flour (5)

T7 - Mushroom (50): Paneer (40): Corn flour (10): Wheat gluten flour (10)

T8 - Mushroom (50): Paneer (35): Corn flour (5): Wheat gluten flour (15)

T9 - Mushroom (50): Paneer (30): Wheat gluten flour (20)

T10 -Mushroom (50): Paneer (30): Wheat gluten flour (25) 
Fig.1 Standardization of meat analog emulsion Fresh button mushroom (Agaricus bisporus)

Cleaned and washed

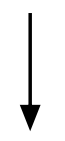

Blanching $\left(60^{\circ} \mathrm{C}\right.$ for $\left.5 \mathrm{~min}\right)$

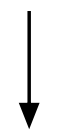

Grinding of blanched mushroom

(Mixer grinder)

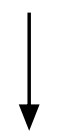

Addition of mushroom, paneer and wheat gluten flour into the planetary mixer

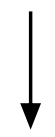

Meat analog emulsion

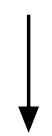

Packing (Aluminium foil package)

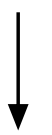

Frozen storage at $-18^{\circ} \mathrm{C}$ 
Stored meat analog emulsion at $-18^{\circ} \mathrm{C}$<smiles>[3H][CH]</smiles>

Thawing

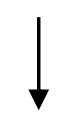

Addition of spices

(Salt, Chilli powder, Pepper powder, Coriander powder, Onion, Ginger and Garlic powder)

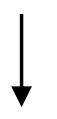

Mixing and kneading

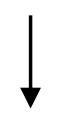

Shape forming using mould

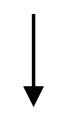

Frying in vegetable oil

Fig.2 Preparation of meat analog

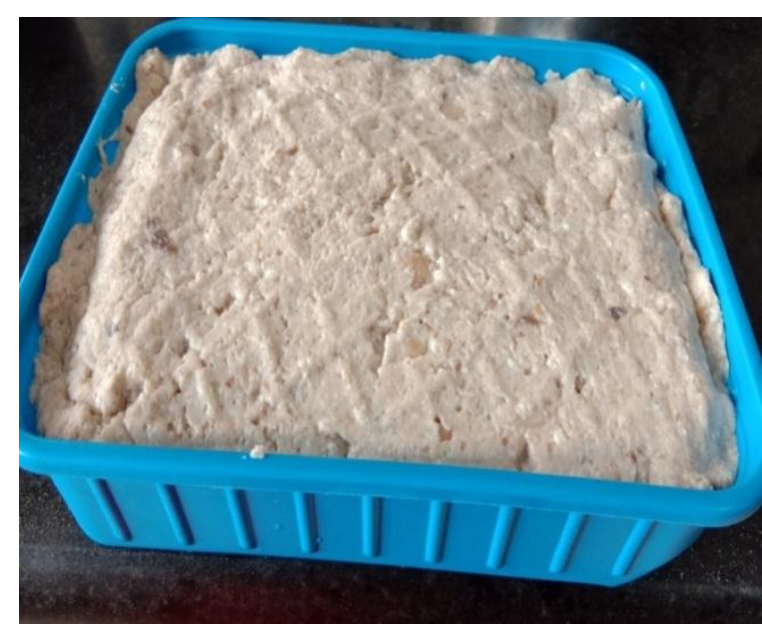

(a) Meat analog emulsion

In the present study as seen in Table 2, there was a significant difference in the sensory perception between control and different

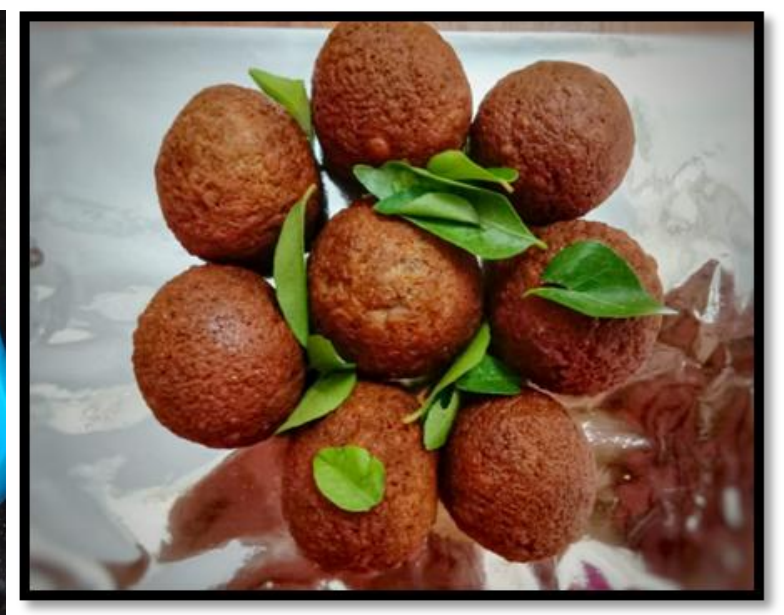

(b) Meat analog product

proportion of treatments viz., T1, T2, T3, T4, T5, T6, T7, T8, T9 and T10. From the scores it was shown that 50:30:20 ratio of 
mushroom, paneer and wheat gluten flour (T9) was preferred by the panelists over other treatments. There was no significant difference between appearance, flavor, taste and overall acceptability of T9 and T10, but a significant difference was observed in terms of juiciness and texture. Among the organoleptic criteria for meat analog texture was given the maximum weight age followed by taste and flavor. Therefore the panelists preferred T9 which possess good texture and juiciness compared with T10. The results obtained for sensory evaluation of meat analog were higher when compared with the findings of Sharima Abdullah et al., (2018) who developed a imitation chicken nuggets from chickpea flour and textured vegetable protein and compared the product with the commercial chicken nuggets in the market.

Highest overall acceptability observed in T9 was mainly contributed by the high score for attributes like appearance, flavor, texture, taste and juiciness. Hence the product was highly acceptable and it satisfies the sensory qualities of meat.

\section{Acknowledgement}

I should thank College of Food and Dairy Technology for utilizing the equipments and facilities for carrying out my research work.

\section{References}

Archana, V., and Neetu, S. (2016). Optimization of mushroom fortified noodles on their sensory attributes. Optimization, 1(6).
Chitranayak, Manjunatha, M., Rekha, M. R., Magdaline, F. E. E., Rao, K. J., Varalakshmi, S., and Deshpande, S. (2017). Physico-chemical characterization of Paneer assessed by varying pressure-time combination. Indian Journal of Dairy Science, 70(3), 280-293.

Craig, W. J. (2010). Nutrition concerns and health effects of vegetarian diets. Nutrition in Clinical Practice, 25(6), 613-620.

Day, L., Augustin, M. A., Batey, I. L., and Wrigley, C. W. (2006). Wheat-gluten uses and industry needs. Trends in food science and technology, 17(2), 82-90.

Joshi, V. K., and Kumar, S. (2015). Meat Analogues: Plant based alternatives to meat products-A review. International Journal of Food and Fermentation Technology, 5(2), 107.

Kumar, P., Chatli, M. K., Mehta, N., Singh, P., Malav, O. P., and Verma, A. K. (2017). Meat analogues: Health promising sustainable meat substitutes. Critical reviews in food science and nutrition, 57(5), 923-932.

Sadler, M. (2003). Nutritional properties of edible fungi. Nutrition Bulletin, 28(3), 305-308.

Sharima-Abdullah, N., Hassan, C. Z., Arifin, N., and Huda-Faujan, N. (2018). Physicochemical properties and consumer preference of imitation chicken nuggets produced from chickpea flour and textured vegetable protein. International Food Research Journal, 25(3), 1016-1025.

\section{How to cite this article:}

Nivetha, B.R., K. Sudha, Rita Narayanan and Vimalarani, M. 2019. Development and Sensory Evaluation of Meat Analog. Int.J.Curr.Microbiol.App.Sci. 8(08): 1283-1288. doi: https://doi.org/10.20546/ijcmas.2019.808.151 